\title{
The Influence of Virtual Alienation in Attention Deficit and Hyperactivity Disorder Adhd): A Systematic Review
}

\author{
Sandra Crisóstomo Bortolanza
}

Lucio Lage Gonçalves, Antonio Egidio Nardi, Anna Lucia Spear King, Psychiatry Institute of the Federal University of Rio de Janeiro / Laboratory Delete - Digital Detox and Conscious Use of Technologies / Brazil.

\author{
*Corresponding author \\ Sandra Crisóstomo Bortolanza, Lucio Lage Gonçalves, Antonio Egidio \\ Nardi, Anna Lucia Spear King, Psychiatry Institute of the Federal University \\ of Rio de Janeiro / Laboratory Delete - Digital Detox and Conscious Use of \\ Technologies / Brazil.
}

Submitted: 23 Jul 2020; Accepted: 28 Jul 2020; Published: 10 Aug 2020

\begin{abstract}
Summary
Introduction: Digital technologies have brought about significant changes in all aspects of life and society. It is relevant to research the new habits of people due to the excessive and unconscious use of digital technologies and their interference in their lives from a psychological point of view, due to the changes it can bring.

Objective: The objective of this work is to present a systematic review on the influence of Virtual Alienation on the behavior of people with Attention Deficit and Hyperactivity Disorder - ADHD, influencing the reinforcement of this disorder.
\end{abstract}

Method: The method used was the bibliographic search concentrated in terms of three keywords described below, in the academic bases PubMed, ISI Web of Science and PsycoInfo, purified according to the PRISMA method.

Results: It has been demonstrated that the main characteristics of Virtual Alienation are in line with the characteristics of ADHD disseminated by DSM-V, which can influence the support of this phenomenon. This investigation is justified by the contribution it can bring to the studies of Psychology, in particular those related to human behavior.

Conclusion: We conclude that the non-conscious use of digital resources can lead to a state of alienation by the Digital Dependence that can cause emotional impacts on people with ADHD.

Keywords: $\mathrm{AL}=$ Alienation; $\mathrm{AV}=$ Virtual Alienation; $\mathrm{ADHD}=$ Attention Deficit and Hyperactivity Disorder; AVCH = Virtual Alienation in Human Behavior.

\section{Introduction}

Alienation is the decrease or abandonment of an individual in exercising his ability to act or think for himself [1]. The term alienation designates repressed contents of consciousness and also, states of depersonalization in which the feeling and awareness of reality are strongly diminished [2].

According to the DSM-V (Diagnostic and Statistical Manual of Mental Disorders) ADHD (Attention Deficit Hyperactivity Disorder) is classified among neurodevelopmental disorders, which are characterized by developmental difficulties that manifest early and their symptoms must appear before 12 years of age (APA, 2014). It can influence personal, social, academic or personal functioning. There is currently no classification of the disorder in relation to symptoms. The traditional subtypes of ADHD, predominantly inattentive, predominantly hyperactiveimpulsive and combined (AMERICAN PSYCHIATRIC ASSOCIATION, 2000) are considered as presentations in the DSM-V (AMERICAN PSYCHIATRIC ASSOCIATION, 2013).

In today's world, digital practices are present in virtually every moment of human life, contributing strongly to the distraction and dispersion of attention. It is possible that the phenomenon of Virtual Alienation promoted by the abusive use and excessively focused on digital media is providing some influence on people with ADHD, in its three subtypes.

The purpose of this article is to describe the influence of Virtual Alienation in individuals with ADHD, particularly in the amplification and reinforcement of this symptom in these people, through the literature on the referred disorder. The discussion that Virtual Alienation causes ADHD is not part of this objective, but 
the perspective of those who already have this disorder, may have expanded it from the presence of Virtual Alienation.

\section{Method}

From the keywords, Alienation; Virtual Alienation; ADHD; Virtual Alienation in Human Behavior, searches were carried out in the PubMed, PsycoInfo and ISI Web of Science databases during the period from $01 / 10 / 2019$ to $03 / 15 / 2020$, aiming to find articles related to those words, with a maximum of six years of publication and with text in the English language without restrictions to the nationalities of the authors. The search resulted in the summary of Table 1, which presents the articles indicated by the aforementioned databases as the first search. Then, the examinations of the Abstracts and the contents of the selected articles as described above, established the numbers of the second search whose articles were effectively used as valid contents of this review, as shown in the table below.

\section{Results}

The searches in the bases of PubMed, ISI Web of Science and PsycINFO initially presented 415 articles. Initially were excluded in the analysis by their titles 106 articles resulting in 309 articles. The analysis of Abstracts eliminated another 254 with 55 remaining. Of these, after full reading of the contents of the articles, 43 were excluded, leaving 12 articles in the final analysis, which is the sum of 7 articles extracted from PubMed with 5 PsycInfo articles, presented in the table totals 1. The main characteristics of the 12 articles included in the qualitative synthesis are described in Table 2, right after the descriptive report of the findings on each selected keyword, below:

\section{Alienation and Virtual Alienation}

The exacerbated focus with which people get involved with digital media put them in a state of alienation from other people and their surroundings. It is a state of lethargy, of exclusion from the environment in which they are, which places them on a virtual plane disconnected from their surroundings. Recent literature has explored the process of global change associated with social, technological and time-saving relationships, as well as relationships and their times. As a result, social practices are changing due to technologies such as the Internet and its new temporal relationships [3]. Teens are spending more and more time with online access. Although it has many benefits, there are also risks related to overuse, as Internet addiction is associated with depression, attention deficit, hyperactivity and other disorders [4]. Negative impacts are created by the abusive and accelerated use of the Internet affecting the attention and work and academic performance, family life, social relationships, physical health and psychological well-being [5]. This practice can contribute to the wandering and alienation of users in the accelerated search that further reinforces the hyperactive and impulsive profile of people with ADHD.

According to Gonçalves it is necessary to observe this acceleration and try to discern the differences between digital time and human time [6]. Digital time tends to be increasingly shorter due to technological developments. Human time is not necessarily equal to digital time, due to human limitations and perverting it can create unnecessary discomfort for man.

\section{Attention Deficit Hyperactivity Disorder - ADHD}

Children with ADHD have an increased risk of the effects of negative experiences on sleep, academic performance, attention and cognitive profile. The suspicious symptoms of ADHD are found in relation to the access of digital media are among the facts that mediate these negative effects [7].

ADHD is a neurobiological disorder characterized by three basic symptoms: inattention, impulsivity and hyperactivity that interferes with development. It is highly correlated with other disorders such as Oppositional Defiant Disorder (TOD), Conduct Disorder (CT) and mood symptoms. The diagnosis of ADHD in later years of preschool showed the same stability for school-age children [8]. ADHD is the most common neurobehavioral disorder during childhood, affecting approximately 3 to $6 \%$ of school-age children. Its main symptoms of hyperactivity, impulsive activities and distractions in behavior can be assumed to have intimate relationships with interferences in motor skills. A part of the literature points to paths with motor problems that can severely impact children's daily lives, with motor problems occurring in 30 to $50 \%$ of children with ADHD [9].

Valença and Nardi point out that this symptomatic triad can complicate various aspects of the individual's life, but it can be modified over the years, and these symptoms can either decrease or increase, showing themselves to be very flexible [10]. That is, a child who presents with the type of attention deficit and hyperactivity may in adult life show impulsive or combined traits. Digital activity, due to its increasing speed, can intensify an ADHD behavior, at least with regard to the referred speed and intensification of activities and excessive focus [11].

On the other hand, the excessive use of computers can be due to the individual's insecurity, generating an uncontrolled impulse, (impulsivity) characterizing dependence, becoming a tool for the construction of a psychotic universe [12]. The detailing of the behaviors that define ADHD can to facilitate the understanding about the possible connection of this disorder with Virtual Alienation, as described below:

\section{Inattention and Attention Deficit}

According to DSM-V (2013), inattention and attention deficit have very specific characteristics that allow their identification due to certain behaviors, such as: (a) Failure to pay attention to detail; (b) Difficulties to maintain sustained attention to tasks; (c) The individuals does not seem to hear when talking to him directly; (d) Often does not follow instructions or fails to complete tasks; (e) Has difficulty organizing tasks or activities; (f) Often misses things necessary to perform tasks; (g) Is easily distracted by external stimuli; (h) Often overlooked in daily activities.

As a neurodevelopmental disorder manifests itself at the beginning of school age, producing personal, social, academic and occupational 
functional weaknesses, accompanied by appropriate intervention by parents and educators, it contributes in a relevant way at school, in family and social interactions, collaborating preventively in the face of future commitments related to the disorder [13]. As the prevalence of ADHD in children is significant, it is important to study possible negative contributions from the digital practices of children in contact with the digital world, in the amplification of hyperactive, impulsive and attention deficit behaviors.

\section{Hyperactivity}

The DSM-V (2013) defines hyperactivity as agitated, often unjustified behavior, characterizing hyperactive people as human beings who cannot stand still, such as: (a) Moves limbs frequently or moves in the chair; (b) Gets up frequently in places where he is expected to remain seated; (c) Runs or climbs excessively on things; (d) Has difficulty playing calmly; (e) It is often "about to" and looks "running on an engine"; (f) Speaks excessively.

\section{Impulsivity}

Similarly, in DSM-V impulsivity is identified when a person cannot control himself and has impulses that are incompatible with the moment or the scenario in which they are immersed. Even knowing the consequences of untimely and unreasonable actions, he takes a position of uncontrollable impulses that can harm himself and others, such as: (a) Explodes in answers before the questions are completed; (b) Has difficulty waiting for his turn; (c) Often interrupts others. The presence and manifestation of the rapid response with impulsivity is proven to be present in children with ADHD [14].

Although the discovery of ADHD predates the Digital Age, in particular the current phase, amplified by the mobility of the fusion of the cell phone with the Internet, it is possible to connect hyperactivity and impulsivity to the speed requirements of digital practices in relation to its users. This can cause greater acceleration in the functional process of children, adolescents and adults.

\section{Virtual Alienation Influencing Adhd}

According to the citations of authors presented in this work, on behaviors aligned with the definitions of Virtual Alienation, it is possible to observe that such behaviors are aligned with the characteristics of ADHD, which can influence and contribute to the reinforcement of this disorder. Detailing the proposal in Table 1 , below, the column on the left, on the quotes of authors, shows definitions for alienation used here, while the column on the right describes characteristics of ADHD that relate, respectively, to each of the citations. ADHD characteristics are being corroborated by the authors' citations.

Table 1: Virtual Disposal x ADHD

\begin{tabular}{|l|l|}
\hline Quotes about Alienation / Virtual Alienation & $\begin{array}{l}\text { Characteristics ADHD (Attention Deficit, } \\
\text { Hyperactivity and Impulsivity) }\end{array}$ \\
\hline $\begin{array}{l}\text { “... decrease or abandonment of an individual in exercising his ability to act or think for } \\
\text { himself” (Gonçalves, 2017). }\end{array}$ & $\begin{array}{l}\text { “.. failure to complete tasks ... difficulty organizing } \\
\text { activities ... loses things to perform tasks" }\end{array}$ \\
\hline Internet addiction is associated with attention deficit and other disorders (Jorgenson, 2016). & Don't listen when they talk to him \\
\hline “... feeling and awareness of reality are greatly diminished (Iglésias, 1981) & Difficulties in maintaining sustained attention to tasks \\
\hline $\begin{array}{l}\text { The presence and implication of the rapid response with impulsivity is characteristic of } \\
\text { children with ADHD (Patros, 2016) }\end{array}$ & $\begin{array}{l}\text { Explodes in answers before the questions are completed, } \\
\text { has difficulty waiting for his turn, often interrupts others. }\end{array}$ \\
\hline $\begin{array}{l}\text { Evidence shows as a conclusion that the excessive use and without guidance of the Internet } \\
\text { can have negative impacts on physical, psychological and social dimensions and on the } \\
\text { development and well-being of children (Ferrara et al, 2017). }\end{array}$ & $\begin{array}{l}\text { He is easily distracted by external stimuli, distancing } \\
\text { himself from other people, and is often forgetful in daily } \\
\text { activities. }\end{array}$ \\
\hline $\begin{array}{l}\text { Human acceleration must be observed and discern between digital and human time. Digital } \\
\text { tends to be faster and faster in the face of technological developments. Human time, not } \\
\text { necessarily, due to human limitations. Perverting him can create unnecessary discomfort for the } \\
\text { man (Gonçalves, 2018) }\end{array}$ & $\begin{array}{l}\text { "Hev from the place where he is expected to remain seated, } \\
\text { runs excessively, has difficulties to play calmly" }\end{array}$ \\
\hline $\begin{array}{l}\text { "Hyper use of computers can be due to anxious insecurity and uncontrolled impulses, } \\
\text { characterizing addiction ...” (Menezes, Peixoto and Veras, 2014). }\end{array}$ & $\begin{array}{l}\text { It is often "on the verge of” "and accelerated, it looks" } \\
\text { on a motor " }\end{array}$ \\
\hline
\end{tabular}

$\mathrm{AL}=$ alienation; $\mathrm{AV}=$ virtual alienation; $\mathrm{ADHD}=$ attention deficit and hyperactivity disorder; $\mathrm{AVCH}=$ virtual alienation in human behavior.

\section{Adhd and the Digital World}

According to King and Nardi, new computer technologies such as software, hardware, telecommunications, among others, in the individual's daily life, have been causing a significant impact in all aspects of life and society, producing behavioral changes in habits and customs, whose effects it cannot be failed to follow [15]. These behavioral changes, derived from technology, are very evident and both children and adults are already very different from the past and the trend is to evolve more and more. Social media are part of everyday life in such a way that relationships have changed, from professional to family relationships. There are more possibilities to learn, connect, control and facilitate. Overstimulation and the development of hyperfocus, which are caused by the parents themselves, can negatively affect if this child already has a tendency or has developed ADHD. According to Adam Leventhal, the exacerbated use of technology can make impulse control very difficult, which is one of the aspects and characteristics of one of the main symptoms of ADHD. The results described are presented quantitatively, according to the diagram below, and were obtained from the researched articles. 


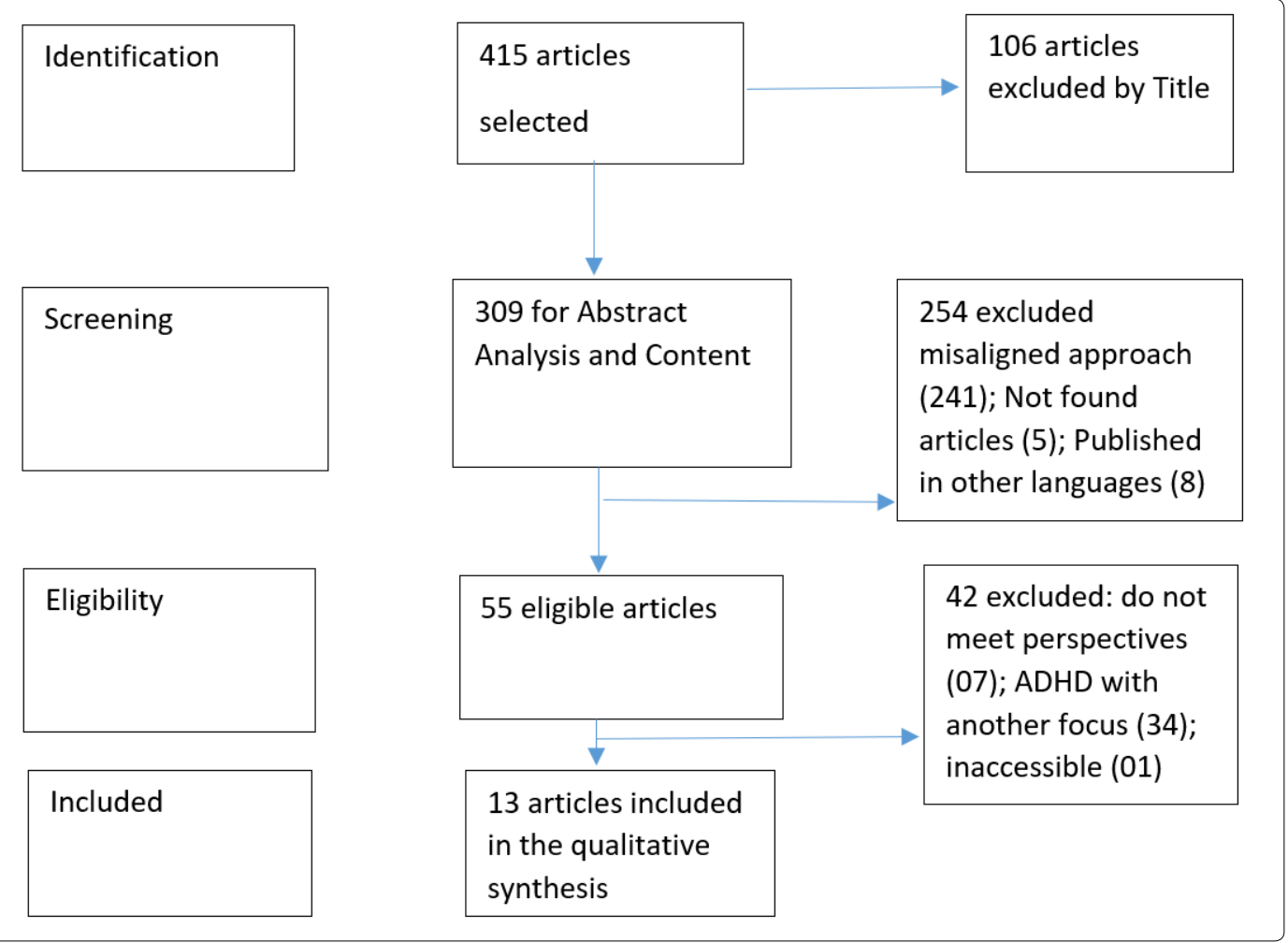

Figure 1: Preferred Reporting Items for Systematic: Reviews and Meta-Analyzes - PRISMA

The results presented, according to the keywords in table 1, follow here, in table 2, with the articles selected in this review, in the qualitative synthesis.

Table 2: Qualitative Synthesis Articles

\begin{tabular}{|c|c|c|c|c|}
\hline & Artigo & Autor & Ano & B.Dados \\
\hline 1. & $\begin{array}{l}\text { Internet addiction and other behavioral addictions. Clin N Am. } 2016 \text { jul; } 25 \text { (3): 509-20. } \\
\text { doi: 10.1016/j.chc.2016.03.004 Epub } 201611 \text { de abril. PMID: } 27338971 \text { Review. }\end{array}$ & Jorgenson AG, Hsiao RC, Yen CF & 2016 & PubMed \\
\hline 2. & $\begin{array}{l}\text { Inattention to Problems with the media, use habits: Interaction between Digital Media, } \\
\text { Use and attention - deficit / hyperactivity and disorder,.Criança Adolescente Psiquiatria } \\
\text { Clin N Am. } 2018 \text { Abr; } 27 \text { (2): 183-191. doi: } 10.1016 \text { / j.chc 2017.11.009. Epub } 20183 \text { de } \\
\text { fevereiro. PMID:29502745 Revisão }\end{array}$ & Ceranoglu TA & 2018 & PubMed \\
\hline 3. & $\begin{array}{l}\text { The Adolescent Child Psychiatr Clin N Am. } 2017 \text { Jul; } 26 \text { (3): 523-538. doi: } 10.1016 / \\
\text { j.chc.2017.02.007. PMID: } 28577607 \text { Revisão. }\end{array}$ & Tandon M, Pergjika A & 2017 & PubMed \\
\hline 4. & $\begin{array}{l}\text { Attention deficit hyperactivity disorder and motor impairment. Abr 2017; } 124 \text { (2): } 425- \\
\text { 440. doi: } 10.1177 / 0031512517690607 \text {. Epub } 201731 \text { de janeiro. PMID:28361657Review. }\end{array}$ & $\begin{array}{l}\text { Goulardins JB, Marques JC, De } \\
\text { Oliveira JA }\end{array}$ & 2017 & PubMed \\
\hline 5. & $\begin{array}{l}\text { Attention - Deficit / Hyperactivity disorder Adv Pediatr. Ago 2016; } 63 \text { (1): 255-80. doi: } \\
\text { 10.1016 / j.yapd.2016.04.017. PMID:27426904Revisão. }\end{array}$ & Leung AK, Hon KL. & 2016 & PubMed \\
\hline 6. & $\begin{array}{l}\text { Treatment approaches for attention deficit hyperactivity disorder Nurs Clin North Am. } \\
\text { 2016 Jun; } 51 \text { (2): 199-211. doi: } 10.1016 \text { / j.cnur.2016.01.005. PMID:27229276Revisão. }\end{array}$ & $\begin{array}{l}\text { Antai-Otong D, } \\
\text { Zimmerman ML }\end{array}$ & 2016 & PubMed \\
\hline 7. & $\begin{array}{l}\text { Choice impulsivity in children and adolescents with ADHD: A meta-analytical review } \\
\text { Clin Psychol Rev. 2016 Feb; 43: 162-74. doi: } 10.1016 \text { / j.cpr.2015.11.001 Epub } 201511 \\
\text { de novembro. PMID:26602954Review. }\end{array}$ & $\begin{array}{l}\text { Patros CH, Alderson RM Kasper } \\
\text { LJ, Tarle SJ, Lea SE, Hudec KL }\end{array}$ & 2016 & PubMed \\
\hline 8. & $\begin{array}{l}\text { Ie Addiction?Temporality and life on line in the network society. Vol.26(3),2017, 267-285. } \\
\text { Society }\end{array}$ & Johnson N.F; Keane, H. Time \& & 2017 & PsycoInfo \\
\hline 9. & $\begin{array}{l}\text { Quality of life in Asia. New York, NY, US: Springer Science plus Business Med. In } \\
\text { Preventing and combating Internet Addiction: A concept review. Lee, Ty, }\end{array}$ & Shek, R.C.F. & 2018 & PsycoInfo \\
\hline 10. & $\begin{array}{l}\text { Internet Addiction: Starting the debate on Health na Well-Being of Children Overexposed } \\
\text { to Digital Media Journal Pediátria. Pettoello-Mantovani, M. }\end{array}$ & $\begin{array}{l}\text { Ferrara, P; Cordélia, G; lannilo F; } \\
\text { Sbordone A; Ehrich, J; Giordino, I; }\end{array}$ & 2017 & PsycoInfo \\
\hline 11. & $\begin{array}{l}\text { Front Psychol, An Affective Neuroscience Framework for the Molecular Dec. 16;7: e.col. } \\
\text { beton. }\end{array}$ & $\begin{array}{l}\text { Montag, C; Sindermann, C; } \\
\text { Becker, B; Dank }\end{array}$ & 2016 & PsycoInfo \\
\hline 12. & $\begin{array}{l}\text { Children's Environmental Health in the Digital Era: Understanding Early Screen Exposure } \\
\text { a Preventable Rusk Factor for Obesity and Sleep Disorder. Children (Basel). }\end{array}$ & $\begin{array}{l}\text { Wolf, C; Wolf, S; Weiss, M; } \\
\text { Nino, G }\end{array}$ & 2017 & PsycoInfo \\
\hline
\end{tabular}




\section{Discussion}

The results found in this systematic review revealed the extent to which people are becoming increasingly involved in the use of digital devices, characterizing the excessive use of technologies and, as a result, showing a state of alienation in relation to the real world due to excessive focus or concentration in the virtual world. Internet use has grown to approximately two billion users, making it common for all age groups. Excessive use and without guidance can generate negative impacts of physical, psychological and social dimensions as well as some material aspects and development of children's well-being [16]. Exposing children to screens offers the potential to become dependent behavior, as they are flooded with levels of sensory stimulation at increasingly younger ages [17]. This type of stimulation in children with ADHD dissociates them from the real world, imposing on them virtual speeds beyond their cognitive abilities, accentuating characteristics of this disorder. Internet addiction, due to its excessive use, represents an emerging global health issue, dramatically transforming the way of living, with greater incidences on children [18-21]. This whole scenario scenario should arouse the attention of Psychology in terms of studying these new behaviors of people, interpreting them and trying to understand them in order to deal with them properly. Considering that the research field of this discipline is interested in human behavior and mainly in its transformations, this work brings a theme that can contribute to the expansion of Psychology as a vital discipline for the improvement of humanity.

As for the limitations of this research, the novelty of the Virtual Alienation theme should be highlighted due to the very emergence of the digital age to transform people in various aspects. These limitations are due to the difficulties in obtaining content that addresses this matter head-on, without, however, making this production unfeasible. On the contrary, it reveals a new perspective on human behavior, specifically ADHD from the perspective of Virtual Alienation, now influenced by a vector derived from new human practices from the digital world.

\section{Conclusions}

The characteristics of ADHD, as shown mainly in table 1, are related to the definitions of Virtual Alienation and can be influenced by this type of alienation, considering that attention deficit, impulsivity and hyperactivity, characteristic trio of ADHD disorder, can be amplified with the digital practices that cause Virtual Alienation. The phenomenon of Virtual Alienation can interfere with ADHD disorder mainly for its expansion, as this work intended to demonstrate. New studies should be carried out in research with main and control groups to expand this perspective.

\section{Financing}

The research was developed with the authors' own resources.

\section{Thanks}

Delete Laboratory - Digital Detox and Conscious Use of Technology@s

IPUB / UFRJ - Institute of Psychiatry, Federal University of Rio de Janeiro
FAPERJ - Carlos Chagas Filho Foundation for Research Support of the State of Rio de Janeiro.

\section{References}

1. American Psychiatric Association (1994) Criteria of the "Diagnostic and Statistical Manual of Mental Disorders" DSM IV1 for Attention Deficit Hyperactivity Disorder (ADHD).

2. American Psychiatric Association (2013) Criteria of the "Diagnostic and Statistical Manual of Mental Disorders" -DSM V for Attention Deficit Hyperactivity Disorder (ADHD).

3. Antai-Otong D, Zimmerman ML (2016) Treatment Approaches for Attention Deficit Hyperactivity Disorder. Nurs Clin North Am. 51: 199-211.

4. Ceranoglu TA (2018) Inattention to Problems with the media, use habits: Interaction between Digital Media, Use and attention - deficit / hyperactivity and disorder, Child Adolescent Psychiatry Clin N Am 27: 183-191.

5. Pietro Ferrara, Giovanni Corsello, Francesca Ianniello, Annamaria Sbordone, Jochen Ehrich, et al. (2017) Internet Addiction: Starting the debate on Health at Well-Being of Children Iverexposed to Digital Media Journal Pediatric 191: 280-281.

6. Gonçalves, Lucio Lage (2018) Coexisting (well) Digital Dependency. Rio de Janeiro: Editora Barra Livros.

7. Gonçalves, Lucio Lage (2017) Digital Dependence: technologies transforming people, relationships and organizations. Rio de Janeiro: Editora Barra Livros.

8. Goulardins JB, Marques JC, De Oliveira JA (2017) Attention deficit hyperactivity disorder and motor impairment 124: 425-440.

9. Iglésias, Francisco (1981) The Industrial Revolution. São Paulo: Editora Brasiliense.

10. Jonhson NF, Keane H (2017) Time \& Ie Addiction? Temporality and life on line in the network; PsycoInfo Society 26: 267-285.

11. Jorgenson AG, Hsiao RC, Yen CF (2016) Internet Addiction and other behavioral addictions. Clin N Am 25: 509-520.

12. King ALS, Nardi AE (2014) What is Nomophobia? History and Concept. In King, ALS, Nardi, AE, Cardoso, A Nomophobia: Computer addiction, Internet, Social Networks, Cell phone addiction. 1st ed., São Paulo, Atheneu Editora.

13. Leung AK, Hon KL (2016) Attention - Deficit / Hyperactivity disorder Adv Pediatr 63: 255-280.

14. Leventhal A (2018) Frequent use of the smartphone may increase ADHD risk in young people. California: Magazine of the American Medical Association (JAMA).

15. Menezes, Peixoto, Veras (2014) From Nomophobia to Nomophrenia: when anxiety turns into Psychosis. In King, ALS, Nardi, AE, Cardoso, A. Nomophobia: Computer addiction, Internet, Social Networks, Cell phone addiction. 1st ed., São Paulo: Atheneu Editora. 
16. Montag C, Sindermann C, Becker B Dank (2016) Front Psychol, An Alfetive Neuroscience Franwork, PsycoInfo for the Molecular Dec. 16; 7: e.col. beton.

17. Patros CH, Alderson RM, Kasper LJ, Tarle SJ, Lea SE, et al. (2016) Choice impulsivity in children and adolescents with ADHD: A meta-analytical review Clin Psychol Rev 43: 162-174.

18. Shek, RCF (2018) Quality of life in Asia. New York, NY, US: Springer Science plus Business Med. In Prerenting and combating Internet Addiction: A concept review. Lee, Ty, PsycoInfo.
19. Tandon M, Pergika (2017) The Adolescent Child Psychiatr Clin N Am 26: 523-538.

20. Valença A, Nardi AE (2015) History of the diagnosis of attention deficit hyperactivity disorder. In: Nardi, Antônio Egídio, Quevedo, João, Silva, Antônio Geraldo (Eds.). Attention deficit / hyperactivity disorder: Theory and Clinic. Porto Alegre: Artmed. Chap 1: 19-22.

21. Wolf C, Wolf S, Weiss M, Nino G (2017) Children's Enviromental Health in the Digital Era; PsycoInfo Understanding Early Screen Exposure a Preventable Rusk, Factor for Obesty and Sleep Disorder. Children (Basel).
Copyright: (2020 Sandra Crisóstomo Bortolanza. This is an open-access article distributed under the terms of the Creative Commons Attribution License, which permits unrestricted use, distribution, and reproduction in any medium, provided the original author and source are credited. 